\title{
Low Molecular Weight Component of Androgen Receptor in Cytosols from Benign Hypertrophic Human Prostate treated with High KCl Solution
}

\author{
TAKAOMI KODAMA, HideKi FUSE AND JUn SHIMAZAKI. \\ Department of Urology, School of Medicine, \\ Chiba University, Chiba 280.
}

\begin{abstract}
Cytosol of the benign hypertrophic human prostate was prepared in a low salt medium and then the concentration of salt was increased to $0.4 \mathrm{M}$ with $\mathrm{KCl}(0.4 \mathrm{M} \mathrm{KCl}$-cytosol). This preparation showed a high affinity binding to $\mathrm{R} 1881$ and the binding was specific for androgens. These results suggest that the binding of the preparation to $R 1881$ was due mainly to the cytosolic androgen receptor. The $\mathrm{R} 1881$ binding component in the $0.4 \mathrm{M}$ $\mathrm{KCl}$-cytosol was sedimented at $3 \mathrm{~S}$ by sucrose density gradient centrifugation. The small sedimentation coefficient of the binder seems to be due to the high concentration of salt and not to degradation by proteolytic enzymes in the preparation. The molecular weight, Stokes radius and frictional ratio of this binding component were $32,000,25.9 \AA$ and 1.24 , respectively.
\end{abstract}

It is well known that the human prostate contains several species of protein which show a high affinity binding to androgens (Menon et al., 1977, Shain and Boesel, 1978). Among these androphilic proteins, androgen receptor, testosterone-binding globulin from blood plasma and progestin-binding protein have been identified in the tissues of the human prostate. As androphilic proteins in the prostate are heterogeneous, it seems to be difficult technically to measure the amounts of androgen receptor separately from other binders. However, using triamcinolone acetonide ( $9 \alpha$-fluoro$11 \beta, 16 \alpha, 17,21$-tetraol-pregna-1,4-dien-3, 20dione cyclic 16,17 acetal with acetone) and R 1881 (methyltrienolone, $17 \beta$-hydroxy-17 $\alpha$ methyl-estra-4,9,11-trien-3-one), several workers claimed that binding of the androgen receptor could be detected in the presence of other androphilic proteins in cytosol of the human prostate (Zava et al., 1979, Asselin et al.,

Received December 22, 1981
1979).

It was also observed that, in a high ionic solution, androgen receptor of rat prostate dissociated into small components (Liao et al., 1975). However, there has been little information about the components of androgen receptor in the human prostate. The present study was undertaken to clarify the properties of the component of androgen receptor which was formed in cytosol of the benign hypertrophic human prostate due to high ionic strength.

\section{Materials and Methods}

\section{Steroids}

Labeled and unlabeled R 1881 ((17 $\alpha$-methyl- $\left.{ }^{3} \mathrm{H}\right)$ $17 \beta$-hydroxy-17 $\alpha$-methyl-estra-4,9,11-trien-3-one, specific activity $87 \mathrm{Ci} / \mathrm{mmol})$ and $\mathrm{R} 5020\left(\left(17 \alpha-\right.\right.$-methyl- $\left.{ }^{3} \mathrm{H}\right)$ 17,21-dimethyl-19-nor-pregna-4,9-dien-3,20-dione, specific activity $87 \mathrm{Ci} / \mathrm{mmol}$ ) were purchased from New England Nuclear (Boston, Mass. U.S.A.). Triamcinolone acetonide was obtained from Sigma Chemical Co., (St. Louis, Mo. U.S.A.). Dihydrotestosterone (17 $\beta$ hydroxy-5 $\alpha$-androstan-3-one) was donated from the 
Teikoku Hormone Co. (Kawasaki, Japan).

\section{Materials}

Tissues of the benign hypertrophic human prostate used in this study were obtained by retropublic procedure from patients admitted to Chiba University Hospital. Immediately after removal, tissues were cut into small pieces, placed on ice, and carried to the laboratory. Some tissues were kept at $-80^{\circ} \mathrm{C}$ until processing. Removed tissues were examined histologically to confirm their pathological state.

\section{Tissue preparation}

Tissues were homogenized in 3 volumes of $0.01 \mathrm{M}$ Tris- $\mathrm{HCl}$ buffer ( $\mathrm{pH}$ 7.4) containing $1 \mathrm{~mm}$ EDTA, $1 \mathrm{~mm}$ $\beta$-mercaptoethanol and $10 \%(\mathrm{w} / \mathrm{v})$ glycerol (TEMG buffer) using a glass homogenizer. The homogenate was filtered through nylon cloth, and centrifuged at $105,000 \times g$ for $60 \mathrm{~min}$ to obtain cytosol (low salt cytosol). Concentrated $\mathrm{KCl}$ solution in TEMG buffer was then added to the low salt cytosol to make the final concentration of $0.4 \mathrm{M}$ with respect to $\mathrm{KCl}(0.4 \mathrm{M} \mathrm{KCl}$ cytosol).

\section{Saturation analysis of the binding}

The $0.4 \mathrm{M} \mathrm{KCl}$-cytosol was incubated in $0.5 \mathrm{ml}$ of TEMG buffer containing $0.4 \mathrm{M} \mathrm{KCl}$, a series concentration of ${ }^{3} \mathrm{H}-\mathrm{R} 1881$ and 1000 -fold molar excess of triamcinolone acetonide at $4{ }^{\circ} \mathrm{C}$ for $20 \mathrm{~h} .{ }^{3} \mathrm{H}-\mathrm{R} 1881$ and triamcinolone acetonide were dissolved in $10 \mu \mathrm{l}$ of ethanol and added to the incubation mixture. All binding experiments were performed in the incubation medium containing $10 \mathrm{mM} \quad \mathrm{Na}_{2} \mathrm{MoO}_{4}$ and $0.5 \mathrm{~mm}$ leupeptin (Sigma Chemical Co., St. Louis, Mo. U.S.A.) except where otherwise indicated. When binding of the low salt cytoso! prepared in TEMG buffer was observed, $0.4 \mathrm{M} \mathrm{KCl}$ was omitted from the incubation mixtures. R 5020 binding of the low salt cytosol and $0.4 \mathrm{M} \mathrm{KCl}-$ cytosol was estimated by incubating with various concentratoins $(0.25-5 \mathrm{nM})$ of ${ }^{3} \mathrm{H}-\mathrm{R} 5020$ at $15^{\circ} \mathrm{C}$ for $3 \mathrm{~h}$ (Kodama et al., 1981).

After incubation, $0.5 \mathrm{ml}$ of TEMG buffer containing $0.05 \%$ dextran (T 70, Pharmacia, Uppsala, Sweden)coated $0.5 \%$ charcoal (Norit A, Wako Pure Chemicals, Osaka, Japan) was added to the incubation mixture, centrifuged, and the radioactivity in an aliquot of the supernatant was counted to obtain the total binding. In palallel incubations, 1000-fold molar excess of unlabeled R 1881 or R 5020 was added to the incubation tube for estimation of the nonspecific binding. The specific binding was calculated from the total binding by subtracting the nonspecific binding. The dissociation constant $(\mathrm{Kd})$ and binding capacity (maximum binding sites) were determined by the method of Scatchard (1949).

\section{Sucrose density gradient centrifugation}

The $0.4 \mathrm{M} \mathrm{KCl-ytosol} \mathrm{was} \mathrm{incubated} \mathrm{in} \mathrm{TEMG}$ buffer containing $5 \mathrm{nM} / \mathrm{H}-\mathrm{R} 1881,0.4 \mathrm{M} \mathrm{KCl}, 10 \mathrm{mM}$
$\mathrm{Na}_{2} \mathrm{MoO}_{4}$ and $0.5 \mathrm{~mm}$ leupeptin in the presence or absence of $5 \mu \mathrm{M}$ triamcinolone acetonide at $4{ }^{\circ} \mathrm{C}$ for $20 \mathrm{~h}$. After incubation, unbound steroid was removed with TEMG buffer containing $0.05 \%$ dextran-coated $0.5 \%$ charcoal, centrifuged, and an aliquot of the mixture was applied on the top of a 5-20\% sucrose gradient in TEMG buffer which contained $0.4 \mathrm{M} \mathrm{KCl}, 10 \mathrm{~mm}$ $\mathrm{Na}_{2} \mathrm{MoO}_{4}$ and $0.5 \mathrm{~mm}$ leupeptin $(5 \mathrm{ml})$. Except where otherwise indicated, centrifugation was performed in a Hitachi Ultracentrifuge (80 P-7, Hitachi Co., Tokyo, Japan) using a RPS $50-2$ rotor at $215,000 \times g$ for $16 \mathrm{~h}$. After centrifugation, the gradient was fractionated into $0.2 \mathrm{ml}$ fractions by a density gradient fractionator (Isco, Model 640, Lincoln, Nebraska, U.S.A.). Human immunoglobulin $\mathrm{G}$ (IgG, 7.0S), equine myoglobulin (Myo, 2.1S) and bovine serum albumin (BSA, 4.6S) were used as references for sedimentation. In parallel incubations, $5 \mu \mathrm{M}$ radioinert $\mathrm{R} 1881$ was added to the incubation medium to observe the location of nonspecific binding.

When the effect of high concentration of salt on the $\mathrm{R} 1881$ binding complex in the low salt cytosol was observed, the low salt cytosol was incubated with ${ }^{3} \mathrm{H}-\mathrm{R}$ 1881 in the absence of $0.4 \mathrm{M} \mathrm{KCl}$. After incubation, the incubation mixture was treated with dextran-coated charcoal, and then the salt concentration was adjusted to $0.4 \mathrm{M}$ with respect to $\mathrm{KCl}$. The incubated cytosol treated with high salt was left at $4^{\circ} \mathrm{C}$ for $60 \mathrm{~min}$, and an aliquot was subjected to sucrose density gradient centrifugation.

\section{Sephadex G-200 Chromatography}

The $0.4 \mathrm{M} \mathrm{KCl-cytosol}$ was incubated in TEMG buffer containing $5 \mathrm{nM}{ }^{3} \mathrm{H}-\mathrm{R} 1881,0.4 \mathrm{M} \mathrm{KCl}, 10 \mathrm{~mm}$ $\mathrm{Na}_{2} \mathrm{MoO}_{4}, 0.5 \mathrm{mM}$ leupeptin and $5 \mu \mathrm{M}$ triamcinolone acetonide in the presence or absence of $5 \mu \mathrm{M}$ unlabeled $\mathrm{R} 1881$ at $4^{\circ} \mathrm{C}$ for $20 \mathrm{~h}$. After incubation, dextrancoated charcoal was added, centrifuged, and an aliquot of the resultant supernatant was applied to a column filled with Sephadex G-200 $(1 \times 87 \mathrm{~cm}$, Pharmacia, Uppsala, Sweden). The column was eluted with TEMG buffer containing $0.4 \mathrm{M} \mathrm{KCl}, 10 \mathrm{mM} \mathrm{Na}_{2} \mathrm{MoO}_{4}$ and $0.5 \mathrm{~mm}$ leupeptin. Each $2 \mathrm{~g}$ fraction was collected. Estimation of molecular weight, Stokes radius and frictional ratio was performed according to the method described by Siegel and Monty (1966).

\section{Analytical Procedures}

Protein was determined by the biuret method (Gornall et al., 1949). Radioactivity was determined in toluene containing $0.4 \%$ PPO and $0.01 \%$ POPOP using a liquid scintillation spectrometer (LKB 1215 Rackbeta, Wallac OY, Finland). Radioactivity in eluates of Sephadex G-200 were estimated in the presence of Insta-Gel (Packard, U.S.A.). 


\section{Results}

Binding of the $0.4 \mathrm{M} \mathrm{KCl}$-cytosol to ${ }^{3} \mathrm{H}-\mathrm{R} 1881$ in the presence or absence of triamcinolone acetonide

Time course of the binding of the $0.4 \mathrm{M}$ $\mathrm{KCl}$-cytosol to ${ }^{3} \mathrm{H}-\mathrm{R} 1881$ in the presence or absence of 1000-fold molar excess of triamcinolone acetonide was examined (Fig. 1). The binding increased gradually with time, and the specific binding reached almost the maximum level after incubation of $16 \mathrm{~h}$. The presence of triamcinolone acetonide did not influence the time course of the binding. Therefore, subsequent incubations of the $0.4 \mathrm{M}$ $\mathrm{KCl}$-cytosol for determination of ${ }^{3} \mathrm{H}-\mathrm{R} 1881$ binding were performed for $20 \mathrm{~h}$.

The $0.4 \mathrm{M} \mathrm{KCl-cytosol}$ was incubated with

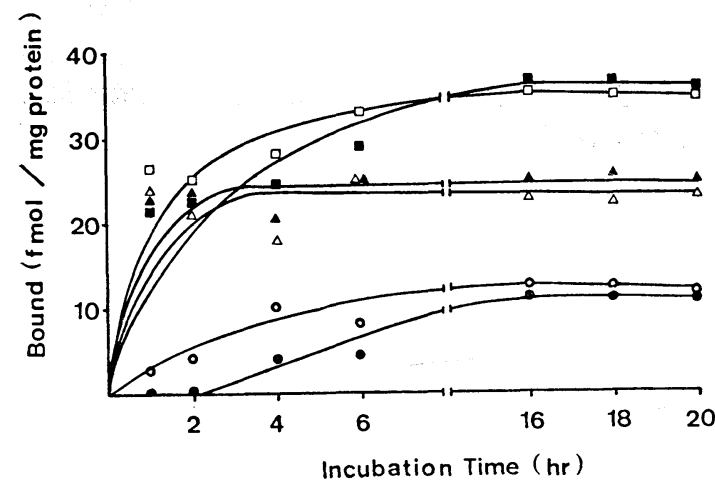

Fig. 1. Time course of the binding of $0.4 \mathrm{M} \mathrm{KCl}$ cytosol to ${ }^{3} \mathrm{H}-\mathrm{R} 1881$.

Cytosol of the benign hypertrophic human prostate was prepared in $10 \mathrm{~mm}$ Tris- $\mathrm{HCl}-1 \mathrm{~mm}$ EDTA$1 \mathrm{~mm} \beta$-mercaptoethanol-10\% glycerol buffer and concentrated $\mathrm{KCl}$ solution was added as to make the concentration of $\mathrm{KCl} 0.4 \mathrm{M}(0.4 \mathrm{M} \mathrm{KCl}$-cytosol). The $0.4 \mathrm{M} \mathrm{KCl}$-cytosol ( $2.5 \mathrm{mg}$ as protein/tube) was incubated with $2.5 \mathrm{nM}{ }^{3} \mathrm{H}-\mathrm{R} 1881$ in the presence (closed symbol) or absence (open symbol) of $2.5 \mu \mathrm{M}$ triamcinolone acetonide at $4^{\circ} \mathrm{C}$ for the various time intervals indicated. All binding experiments in this and the following Fig. were performed in the medium containing $0.4 \mathrm{M} \mathrm{KCl}, 10 \mathrm{mM} \mathrm{Na} \mathrm{MoO}_{4}$ and $0.5 \mathrm{~mm}$ leupeptin except where otherwise indicated. Total binding $(\square)$, specific binding (๑), nonspecific binding $(\Delta \Delta)$. various concentrations of ${ }^{3} \mathrm{H}-\mathrm{R} 1881$ in the presence or absence of triamcinolone acetonide to estimate the binding parameters (Fig. 2). The $0.4 \mathrm{M} \mathrm{KCl-cytosol} \mathrm{showed} \mathrm{a} \mathrm{binding} \mathrm{of}$ single high affinity nature to ${ }^{3} \mathrm{H}-\mathrm{R} 1881$ and influence of triamcinolone acetonide on the binding seems to be, if any, relatively small. This suggests that the $0.4 \mathrm{M} \mathrm{KCl}$-cytosol contains a ${ }^{3} \mathrm{H}-\mathrm{R} 1881$ binding component, the binding of which is relatively resistant to addition of triamcinolone acetonide.

To examine whether the $0.4 \mathrm{M} \mathrm{KCl}$-cytosol contains component(s) bound to progestin or not, the $0.4 \mathrm{M} \mathrm{KCl}$-cytosol and the low salt cytosol were independently incubated with ${ }^{3} \mathrm{H}-\mathrm{R} 5020$ (Fig. 3). The low salt cytosol showed a high affinity binding to ${ }^{3} \mathrm{H}-\mathrm{R} 5020$, but in the $0.4 \mathrm{M} \mathrm{KCl}$-cytosol no specific binding to ${ }^{3} \mathrm{H}-\mathrm{R} 5020$ was detected.

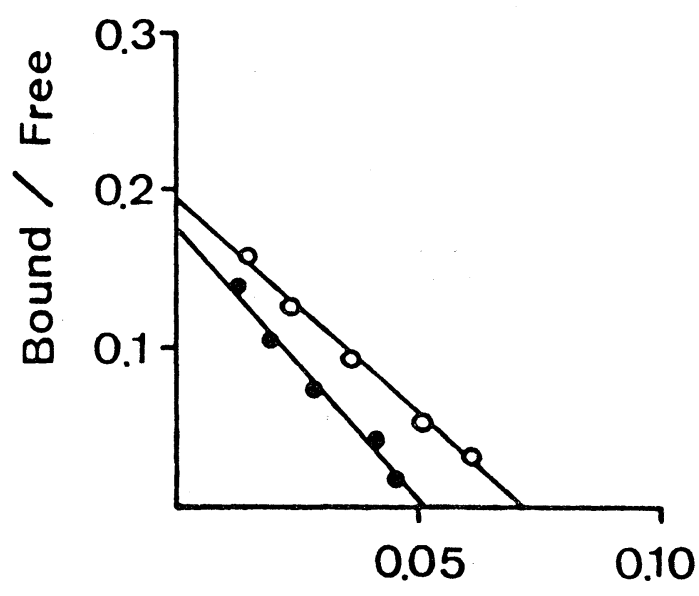

\section{Bound ( pmol)}

Fig. 2. Binding of $0.4 \mathrm{M} \mathrm{KCl}$-cytosol to ${ }^{3} \mathrm{H}-\mathrm{R} 1881$. The $0.4 \mathrm{M} \mathrm{KCl}$-cytosol ( $2.8 \mathrm{mg}$ as protein/tube) was incubated with various concentrations $(0.25-5 \mathrm{nM})$ of ${ }^{3} \mathrm{H}-\mathrm{R} 1881$ in the presence (closed circle) or absence (open circle) of 1000 -fold molar excess of triamcinolone acetonide at $4^{\circ} \mathrm{C}$ for $20 \mathrm{~h}$. $\mathrm{Kd}$ and maximum binding sites were calculated from the Fig. as $0.7 \times 10^{-9} \mathrm{M}$ and $19 \mathrm{fmol} / \mathrm{mg}$ protein in the presence of triamcinolone acetonide and $0.9 \times 10^{-9} \mathrm{M}$ and $25 \mathrm{fmol} / \mathrm{mg}$ protein in the absence of triamcinolone acetonide, respectively. 


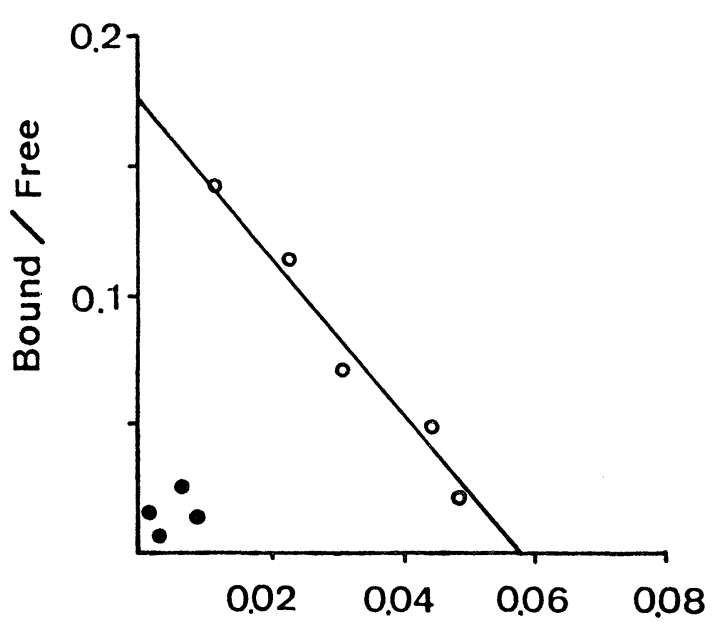

\section{Bound (pmol)}

Fig. 3. Binding of $0.4 \mathrm{M} \mathrm{KCl}$-cytosol and of low salt cytosol to ${ }^{3} \mathrm{H}-\mathrm{R} 5020$.

The $0.4 \mathrm{M} \mathrm{KCl}$-cytosol $(2.9 \mathrm{mg}$ as protein/tube, closed circle) or the low salt cytosol $(2.9 \mathrm{mg}$ as protein/tube, open circle) were incubated with various concentrations $(0.25-5 \mathrm{nM})$ of ${ }^{3} \mathrm{H}-\mathrm{R} 5020$ at $15^{\circ} \mathrm{C}$ for $3 \mathrm{~h} .0 .4 \mathrm{M} \mathrm{KCl}$ was omitted from the incubation mixture for the determination of the binding with the low salt cytosol. $\mathrm{Kd}$ and maximum binding sites of the binding of the low salt cytosol were calculated from the Fig. as $0.7 \times 10^{-9} \mathrm{M}$ and $22 \mathrm{fmol} /$ mg protein, respectively.
Inhibition of ${ }^{3} \mathrm{H}-\mathrm{R} 1881$ binding in the $0.4 \mathrm{M}$ KCl-cytosol by various steroids

The $0.4 \mathrm{M} \mathrm{KCl-cytosol} \mathrm{was} \mathrm{incubated} \mathrm{with}$ $1 \mathrm{nM}{ }^{3} \mathrm{H}-\mathrm{R} 1881$ in the presence or absence of triamcinolone acetonide supplemented with various concentrations (10-1000 nM) of unlabeled additives (Fig. 4). Binding to ${ }^{3} \mathrm{H}-\mathrm{R}$ 1881 of the $0.4 \mathrm{M} \mathrm{KCl}$-cytosol was significantly inhibited by $\mathrm{R} 1881$ and dihydrotestosterone, but R 5020 was a weak inhibitor irrespective of the presence or absence of triamcinolone acetonide. Triamcinolone acetonide inhibited the binding silghtly. The addition of triamcinoone acetonide to the incubation did not modify the pattern of inhibition by various steroids.

Sedimentation and chromatographic analysis of the binding

The $0.4 \mathrm{M} \mathrm{KCl}$-cytosol prelabeled with $5 \mathrm{nM}{ }^{3} \mathrm{H}-\mathrm{R} 1881$ in the presence or absence of triamcinolone acetonide was fractionated in the sucrose density gradient centrifugation (Fig. 5A). A peak of 3S was evident irrespective of the presence of triamcinolone acetonide. In incubation with an excessive amount of

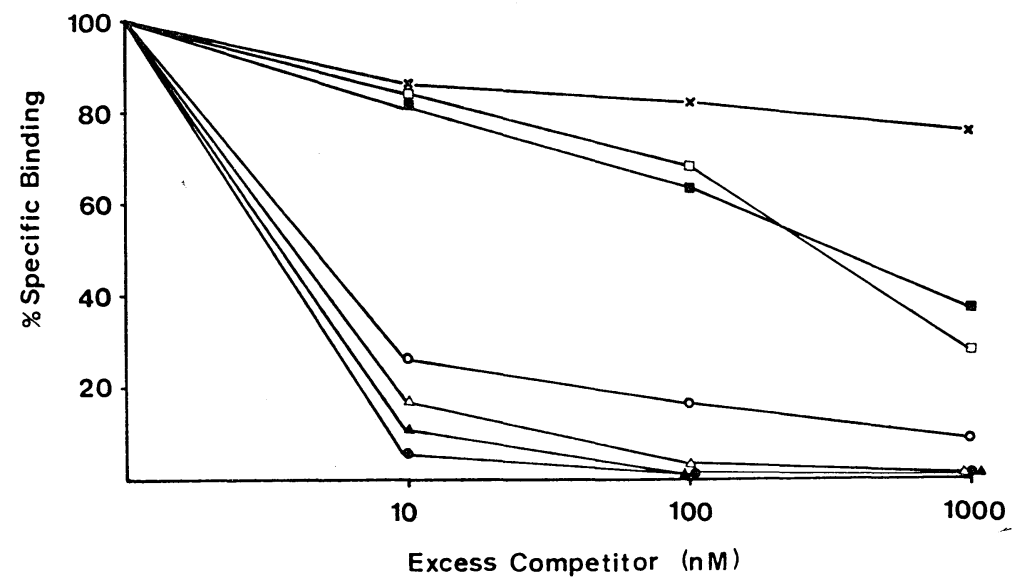

Fig. 4. Inhibition of ${ }^{3} \mathrm{H}-\mathrm{R} 1881$ binding in $0.4 \mathrm{M} \mathrm{KCl}$-cytosol by various steroids.

The $0.4 \mathrm{M} \mathrm{KCl}$-cytosol $\left(2.1 \mathrm{mg}\right.$ as protein/tube) was incubated with $1 \mathrm{nM}{ }^{3} \mathrm{H}-\mathrm{R} 1881$ in the presence of various concentrations $(10-1000 \mathrm{nM})$ of radioinert competitors supplemented with (closed symbol) or without (open symbol and cross) $1 \mu \mathrm{M}$ triamcinolone acetonide at $4^{\circ} \mathrm{C}$ for $20 \mathrm{~h}$. The binding was expressed as a percentage of that incubated in the absence of competitors $(19 \mathrm{fmol} / \mathrm{mg}$ protein with triamcinolone acetonide and $21 \mathrm{fmol} / \mathrm{mg}$ protein without triamcinolone acetonide). circle (dihydrotestosterone), triangle ( $R$ 1881), square ( $R$ 5020), cross (triamcinolone acetonide). 


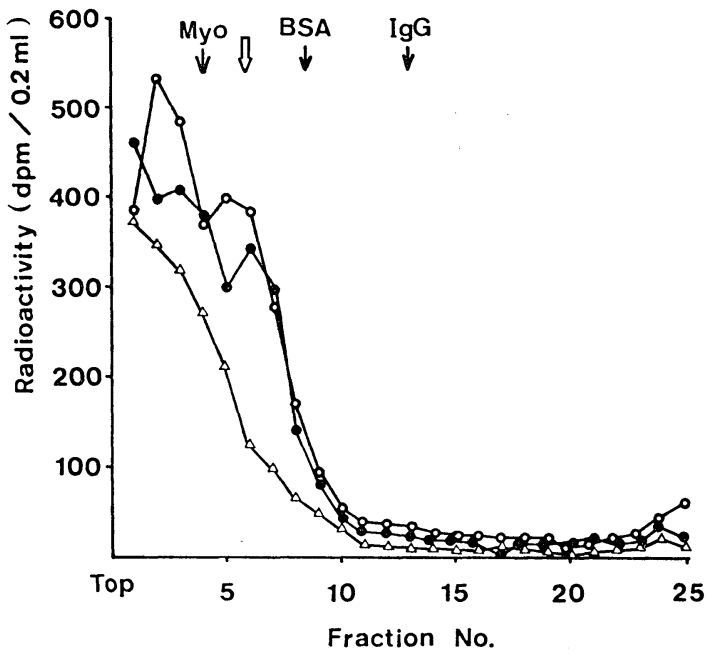

(A)

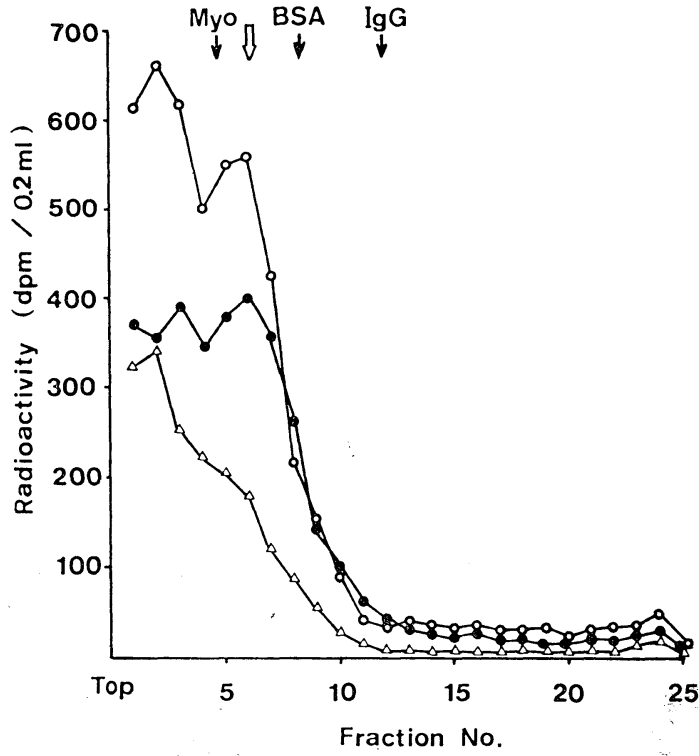

(B)

Fig. 5. Sucrose density gradient centrifugation in high salt solution of $0.4 \mathrm{M} \mathrm{KCl-cytosol}$ (A) or of cytosol

(B) bound with ${ }^{3} \mathrm{H}-\mathrm{R} 1881$.

A: The $0.4 \mathrm{M} \mathrm{KCl}$-cytosol was incubated with $5 \mathrm{nM}{ }^{3} \mathrm{H}-\mathrm{R} 1881$ and $5 \mu \mathrm{M}$ triamcinolone acetonide at $4{ }^{\circ} \mathrm{C}$ for $20 \mathrm{~h}$. After separating unbound steroid an aliquot $(0.3 \mathrm{ml}, 1.0 \mathrm{mg}$ as protein) was applied on the top of a $5-20 \%$ sucrose gradient containing $0.4 \mathrm{M} \mathrm{KCl}, 10 \mathrm{mM} \mathrm{Na}_{2} \mathrm{MoO}_{4}, 0.5 \mathrm{~mm}$ leupeptin and $10 \%$ glycerol, and centrifuged at $215,000 \times g$ for $16 \mathrm{~h}$. Each $0.2 \mathrm{ml}$ fraction was collected and the radioactivity in each fraction was counted (closed circle). In parallel incubations, triamcinolone acetonide was omitted (open circle) or $5 \mu \mathrm{m}$ unlabeled R 1881 was added (open triangle). The site of the binding component is indicated by the white arrow. Black arrows indicate the location of markers (IgG; human immunoglobulin G (7.0S), Myo; equine myoglobulin (2.1S), BSA; bovine serum albumin (4.6S)).

B: The low salt cytosol was incubated with $5 \mathrm{nM}{ }^{3} \mathrm{H}-\mathrm{R} 1881$ in the medium containing $10 \mathrm{mM} \mathrm{Na}_{2} \mathrm{MoO}_{4}$ and $0.5 \mathrm{~mm}$ leupeptin supplemented with (closed circle) or without (open circle) $5 \mu \mathrm{M}$ triamcinolone acetonide. After removing unbound steroid, concentration of $\mathrm{KCl}$ in the supernatant was adjusted to $0.4 \mathrm{M}$ and left at $4^{\circ} \mathrm{C}$ for $60 \mathrm{~min}$. An aliquot $(0.3 \mathrm{ml}, 0.8 \mathrm{mg}$ as protein) was fractionated by sucrose density gradient centrifugation. open triangle; nonspecific binding.

unlabeled $\mathrm{R} 1881$, this peak was not observed.

The low salt cytosol was incubated with ${ }^{3} \mathrm{H}-\mathrm{R} 1881$ in the presence or absence of triamcinolone acetonide. After incubation, dextran-coated charcoal was mixed and centrifuged and then the $\mathrm{KCl}$ concentration in the resultant supernatant was adjusted to $0.4 \mathrm{M}$. An aliquot of this mixture was analyzed in the sucrose density gradient centrifugation (Fig. 5B). A radioactive peak of $3 \mathrm{~S}$ was also observed regardless of the presence of triamcinolone acetonide.

To estimate the sedimentation coefficient of the binding components accurately, the $0.4 \mathrm{M}$ $\mathrm{KCl}$-cytosol prelabeled with ${ }^{3} \mathrm{H}-\mathrm{R} 1881$ was fractionated with more centrifugal force (Fig. 6). A peak of $3 \mathrm{~S}$ was again confirmed, separating from the radioactivity of the first few fractions due to dissociated free ${ }^{3} \mathrm{H}$-steroid.

To examine whether proteolytic enzymes in the sample were involved in the formation of $3 \mathrm{~S}$ peak or not, the $0.4 \mathrm{M} \mathrm{KCl}$-cytosol was incubated with $5 \mathrm{nM}{ }^{3} \mathrm{H}-\mathrm{R} 1881$ in the incubation medium without leupeptin, and further analyzed in the sucrose density gradient centrifugation (Fig. 7). A radioactive peak was 


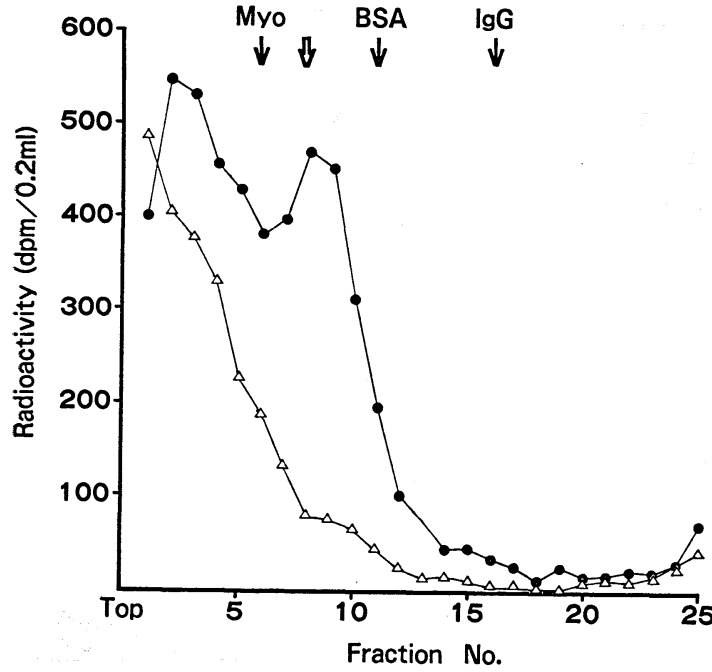

Fig. 6. Sedimentation profile of ${ }^{3} \mathrm{H}-\mathrm{R}$ 1881-bound $0.4 \mathrm{M} \mathrm{KCl}$-cytosol in high salt solution.

The $0.4 \mathrm{M} \mathrm{KCl}$-cytosol was incubated with ${ }^{3} \mathrm{H}-\mathrm{R}$ 1881 described in Fig. $5 \mathrm{~A}$ and an aliquot $(0.3 \mathrm{ml}$, $0.9 \mathrm{mg}$ as protein) was analyzed by sucrose density gradient centrifugation performed at $215,000 \times g$ for $25 \mathrm{~h}$. Total binding (closed circle), nonspecific binding (open triangle).

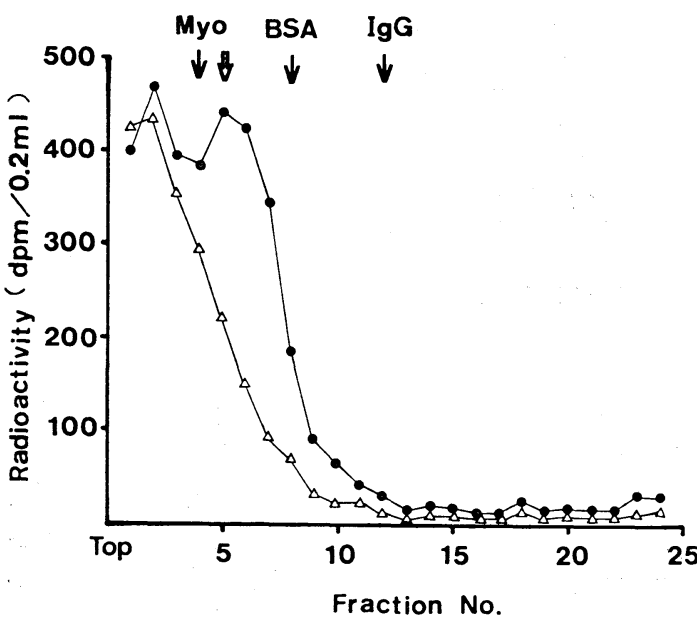

Fig. 7. Sedimentation profile of ${ }^{3} \mathrm{H}-\mathrm{R}$ 1881-bound $0.4 \mathrm{M} \mathrm{KCl}$-cytosol prepared in the medium without leupeptin.

The $0.4 \mathrm{M} \mathrm{KCl}$-cytosol was incubated with ${ }^{3} \mathrm{H}-\mathrm{R}$ 1881 and an aliquot $(0.3 \mathrm{ml}, 0.9 \mathrm{mg}$ as protein) was analyzed by sucrose density gradient centrifugation. All procedures were performed in the medium omitted leupeptin. Total binding (closed circle), nonspecific binding (open triangle).

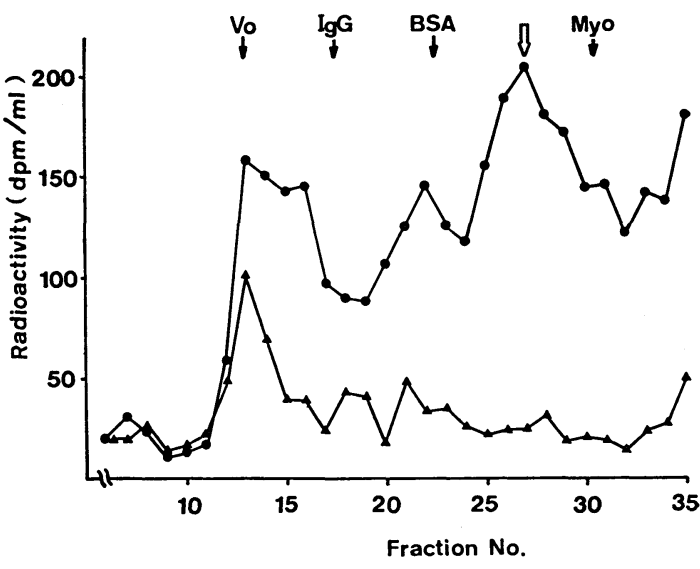

Fig. 8. Sephadex G-200 chromatography of $0.4 \mathrm{M}$ $\mathrm{KCl}$-cytosol prelabeled with ${ }^{3} \mathrm{H}-\mathrm{R} 1881$.

The $0.4 \mathrm{M} \mathrm{KCl}$-cytosol was incubated with $5 \mathrm{~nm}$ ${ }^{3} \mathrm{H}-\mathrm{R} 1881$ and $5 \mu \mathrm{M}$ triamcinolone acetonide at $4{ }^{\circ} \mathrm{C}$ for $20 \mathrm{~h}$. After dextran-coated charcoal treatment, an aliquot (3.1 $\mathrm{mg}$ as protein) was applied to the Sephadex G-200 column $(1 \times 87 \mathrm{~cm})$. The column was eluted with TEMG buffer containing $0.4 \mathrm{M} \mathrm{KCl}$, $10 \mathrm{~mm} \mathrm{Na} \mathrm{MoO}_{4}$ and $0.5 \mathrm{~mm}$ leupeptin at a flow rate of $5.1 \mathrm{ml} / \mathrm{h}$. Each $2 \mathrm{~g}$ of the eluate was collected and the radioactivity in an aliquot of the eluate was counted (closed circle). Nonspecific binding (closed triangle). Vo; void volume, IgG; human immunoglobulin G, Myo; equine myoglobulin, BSA; bovine serum albumin.

observed in the same fraction as that incubated with leupeptin. It was also confirmed that a $3 \mathrm{~S}$ peak was obtained when leupeptin was added to the homogenization medium. Therefore, the possibility of digestion by proteolytic enzyme at the time of homogenization and tissue fractionation could be neglected.

The $0.4 \mathrm{M} \mathrm{KCl-cytosol} \mathrm{labeled} \mathrm{with}{ }^{3} \mathrm{H}-\mathrm{R}$ 1881 in the manner described above was applied to a Sephadex G-200 column (Fig. 8). Some radioactive materials appeared just after the void volume and at the site of BSA, but a considerable amount of binding component was eluted between the elution site of BSA and that of Myo. The first peak seems to be due to aggregation of the third binding component, since the latter shifted to a void volume fraction after dialysis and rechromatography. 
The small binding component eluted at the elution site of BSA might be other binding protein, but the nature of this binding was not further examined.

Together with the results of sedimentation experiments, the main binding component in the $0.4 \mathrm{M} \mathrm{KCl}$-cytosol was assumed to be a low molecular weight component that sedimented at $3 \mathrm{~S}$ on sucrose density gradient centrifugation and was eluted between the elution site of BSA and that of Myo in Sephadex G-200 column chromatography. The molecular weight of this binding component was calculated as approximately 32,000 , and Stokes radius and frictional ratio were estimated as $25.9 \AA$ and 1.24 , respectively.

\section{Discussion}

A higher rate of inhibition by progestins than dihydrotestosterone was observed in the binding to $\mathrm{R} 1881$ of cytosol from the human prostate, but when the incubation mixture for the binding included triamcinolone acetonide, dihydrotestosterone exhibited a potent inhibition of the R 1881 binding (Hicks and Walsh, 1979). Therefore, the $R 1881$ binding of the human prostatic cytosol in the presence of triamcinolone acetonide seems to be attributable to the binding of androgen receptor. The addition of molybdate stabilizes the binding to $\mathrm{R} 1881$ in the cytosol from the human prostate as has been observed in the rodent prostate (Gaubert et al., 1980, Noma et al., 1980, Trachtenberg et al., 1981). Based on these observations the determination of the specific binding by the androgen receptor in the human prostate has been improved, and the current method used for the examination of receptor in the human prostatic tissues includes triamcinolone acetonide and molybdate in the incubation medium (Shimazaki et al., 1981).

In the present study, it is revealed that the human prostatic cytosol treated with $0.4 \mathrm{M}$ $\mathrm{KCl}$ shows a high affinity binding to $\mathrm{R} 1881$, and this binding seems to be attributable to that of the androgen receptor. The rate of binding to androgens in the rat prostate was not influenced by the ionic strength of the incubation medium (Fang et al., 1969). Incubations of the $0.4 \mathrm{M} \mathrm{KCl}$-cytosol from the human prostate in the present experiments were performed in the presence of triamcinolone acetonide but the omission of triamcinolone acetonide from the incubation media did not cause significant changes in the $\mathrm{R} 1881$ binding. In addition, since no $0.4 \mathrm{M} \mathrm{KCl}$-cytosol binding of progestin was observed, therefore, the $\mathrm{R}$ 1881 binding of the $0.4 \mathrm{M} \mathrm{KCl}$-cytosol seems to be due to the binding by the androgen receptor. The reason why the binding to progestin is inhibited in high ionic medium is not clear but the binding component with progestin in the human prostatic cytosol does not seem to be steroid receptor but another binding protein (Kodama et al., 1981). It is possible that the binding of the latter to ligand is easily influenced by ionic strength.

Many reports indicated that the androgen receptor of the rat prostate showed a sedimentation coefficient of $8 \mathrm{~S}$ in low salt solutions (Liao, 1975, Gorski and Gannon, 1976, Bradlow and Gasparini, 1979). However, 3S component has been generally observed in androgen receptors of the various androgen-target tissues of the rodent (Lea et al., 1979, Wilson and French, 1979). It is assumed that androgen receptor sedimented in $8 \mathrm{~S}$ is the complex of 3S component and other macromolecules (Wilson and French, 1976, Liao, 1977), although it is still discussed that the $8 \mathrm{~S}$ androgen receptor is a dimer consisting of small subunits, as was suggested concerning estrogen receptor (Gorski and Gannon, 1976). In cytosols of the human prostate, the R 1881 binding component which has a sedimentation coefficient of approximately $8 \mathrm{~S}$ in low ionic medium was observed (Kodama et al., 1980). Under the high ionic conditions, it was reported that the molecular size of the dihydrotestosteronebinding component was decreased (Mainwaring and Milroy, 1973). In the present study, it can be shown that the sedimentation coeffi- 
cient of the human androgen receptor is $3 \mathrm{~S}$ in the high salt solution and this $3 \mathrm{~S}$ component still possesses the binding ability to $\mathrm{R} 1881$ under the high ionic conditions. Furthermore, the $8 \mathrm{~S}$ binding protein which binds to $\mathrm{R} 1881$ dissociates to $3 \mathrm{~S}$ in the presence of $0.4 \mathrm{M} \mathrm{KCl}$. Among the steroid hormone binding protein so far examined, $3 \mathrm{~S}$ component which exhibits the intact binding ability to androgens seems to be the smallest one. However, the $3 \mathrm{~S}$ binding component in the human prostate observed in the present study is not likely to be an artificial product of proteolytic digestion, since omitting leupeptin, the potent inhibitor of protease (Umezawa, 1976, Aoyagi et al., 1969, Sherman et al., 1980, Hazato and Murayama, 1981), from the incubation medium as well as from the homogenizing medium, did not modify the sedimentation profile of the $\mathrm{R} 1881$ binding component in the $0.4 \mathrm{M} \mathrm{KCl}$-cytosol. Recently a $3 \mathrm{~S}$ subunit of estrogen receptor called meroreceptor was derived from the $8 \mathrm{~S}$ receptor by treatment with trypsin or chaotropic salt, NaSCN (Miller, 1980, Sica et al., 1976, Bailly et al., 1980, Sherman et al., 1978, Erdos et al., 1977, Vallet-Strouve et al., 1976). The androgen receptor of the human prostate observed in the present study dissociates more easily to the smallest component in high salt solution. Moreover, the 3S androgen receptor still contains R 1881 binding site, and this seems to be similar to that reported in the meroreceptor. Further studies to clarify the physiological significance of $3 \mathrm{~S}$ binding component will be awaited.

\section{Acknowledgements}

This work was supported in part by Grants-in-Aid for Cancer Research from the Ministry of Health and Welfare and from the Ministry of Education, Science and Culture, and for Scientific Research from the Ministry of Education, Science and Culture, Japan.

\section{References}

Aoyagi, T., T. Takeuchi, A. Matsuzaki, K. Kawamura,
S. Kondo, M. Hamada, K. Maeda and H. Umezawa (1969). Leupeptins, new protease inhibitors from actinomycetes. J. Antibiot. 22, 283-286.

Asselin, J., R. Mélançon, Y. Gourdeau, F. Labrie, C. Bonne and J. P. Raynaud (1979). Specific binding of $\left({ }^{3} \mathrm{H}\right)$-methyltrienolone to both progestin and androgen binding components in human benign prostatic hypertrophy (BPH). J. Steroid Biochem. $10,483-486$.

Bailly, A., B. L. Fevre, J. F. Savouret 'and E. Milgrom (1980). Activation and changes in sedimentation properties of steroid receptors. J. Biol. Chem. 255 , 2729-2734.

Bradlow, H. L. and F. J. Gasparini (1979). Current status of prostate androgen receptors. Ann. Clin. Lab. Sci. 9, 299-313.

Erdos, T., R. Bessada and J. Fries (1977). Multiple molecular forms of the uterine estradiol receptor. In "Multiple molecular forms of steroid hormone receptors" (M. K. Agarwal, ed.) Elsevier. NorthHolland, Amsterdam. pp. 113-128.

Fang, S., K. M. Anderson and S. Liao (1969). Receptor proteins for androgens. On the role of specific proteins in selective retention of $17 \beta$-hydroxy- $5 \alpha$ androstan-3-one by rat ventral prostate in vivo and in vitro. J. Biol. Chem. 244, 6584-6595.

Gaubert, C. M., R. R. Tremblay and J. Y. Dubé (1980). Effect of sodium molybdate on cytosolic androgen receptors. J. Steroid Biochem. 13, 931-937.

Gornal, A. G., C. J. Bardawill and M. M. David 1949). Determination of serum proteins by means of the biuret reaction. J. Biol. Chem. 177, 751-766.

Gorski, J. and F. Gannon (1976). Current models of steroid hormone action: A critique. Ann. Rev. Physiol. 38, 425-449.

Hazato, T. and A. Murayama (1981). Protection of steroid hormone receptors by protease inhibitors. Biochem. Biophys. Res. Commun. 98, 488-493.

Hicks, L. L. and P. C. Walsh (1979). A microassay for the measurement of androgen receptors. Steroids 33, 389-406.

Kodama, T., C. Hasebe and J. Shimazaki (1980). Binding to R 1881 (methyltrienolone) of proteins from human benign prostatic hypertrophy. Endocrionol. Japon. 27, 229-237.

Kodama, T., M. Ito, R. Sato, H. Ito and J. Shimazaki (1981). Progestin-binding protein in human benign prostatic hypertrophy. Endocrinol. Japon. 28, 175185.

Lea, O. A., E. M. Wilson and F. S. French (1979). Characterization of different forms of the androgen receptor. Endocrinology 105, 1350-1360.

Liao, S. (1975). Cellular receptors and mechanisms of action of steroid hormones. Int. Rev. Cytol. 41, 87-172.

Liao, S. (1977). Molecular actions of androgens. In "Biochemical actions of hormones". Vol. IV (G. Litwack ed.). Academic Press. New York and London, pp. 351-406. 
Liao, S., J. L. Tymoczko, E. Castañeda and T. Liang (1975). Androgen receptors and androgen-dependent initiation of protein synthesis in the prostate. Vitam. Horm. 33, 297-317.

Mainwaring, W. I. P. and J. G. Milroy (1973). Characterization of the specific androgen receptors in the human prostate gland. J. Endocrinol. 57, 371-384.

Menon, M., C. E. Tananis, M. G. McLoughlin and P. C. Walsh (1977). Androgen receptors in human prostatic tissue: A review. Cancer Treat. Rep. 61, 265-271.

Miller, L. K. (1980). The mero-receptor. In "Biochemical actions of hormones" Vol. VII (G. Litwack ed.) Academic Press, New York and London. pp. 233-243.

Noma, K., K. Nakao, B. Sato, Y. Nishizawa, K. Matsumoto and Y. Yamamura (1980). Effect of molybdate on activation and stabilization of steroid receptors. Endocrinology 107, 1205-1211.

Scatchard, G. (1949). The attractions of proteins for small molecules and ions. Ann. N. Y. Acad. Sci. 15, 660-672.

Shain, S. A. and R. W. Boesel (1978). Human prostate steroid hormone receptor quantitation. Current methodology and possible utility as a clinical discriminant in carcinoma. Invert. Urol. 16, 169175.

Sherman, M. R., L. A. Pickering, F. M. Rollwagen and L. K. Miller (1978). Mero-receptors: Proteolytic fragments of receptors containing the steroid-binding site. Fed Proc. 37, 167-173.

Sherman, M. R., F. B. Tuazon and L. K. Miller (1980). Estrogen receptor cleavage and plasminogen activation by enzymes in human breast tumor cytosol. Endocrinology 106 1715-1727.

Shimazaki, J., T. Hikage, R. Sato, T. Kodama and H. Ito (1981). Measurement of androgen receptor in cytosols from normal, benign hypertrophic and cancerous human prostates. Endocrinol. Japon. 28, 725-734.

Sica, V., E. Nola, G. A. Puca and F. Bresciani (1976). Estrogen binding proteins of calf uterus. Inhibition of aggregation and dissociation of receptor by chemical perturbation with NaSCN. Biochemistry 15, 1915-1923.

Siegel, L. M. and K. J. Monty (1966). Determination of molecular weights and frictional ratios of proteins in impure systems by use of gel filtration and density gradient centrifugation. Application to crude preparations of sulfite and hydroxylamine reductases. Biochim. Biophys. Acta 112, 346-362.

Trachtenberg, J., L. L. Hicks and P. C. Walsh (1981). Methods for the determination of androgen receptor content in human prostatic tissue. Invest. Urol. 18, 349-354.

Umezawa, H. (1976). Structures and activities of protease inhibitors of microbial origin. Methods Enzymol. 45, 678-695.

Vallet-Strouve, C., L. Rat and J. M. Sala-Trepat (1976). Limited proteolysis of cytoplasmic and nuclear uterine estradiol receptors yields identical estradiolbinding fragments. Eur. J. Biochem. 66, 327-337.

Wilson, E. M. and F. S. French (1976). Binding properties of androgen receptors. Evidence for identical receptors in rat testis, epididymis, and prostate. J. Biol. Chem. 251, 5620-5629.

Wilson, E. M. and F. S. French (1979). Effects of proteases and protease inhibitors on the $4.5 \mathrm{~S}$ and $8 \mathrm{~S}$ androgen receptor. J. Biol. Chem. 254, 6310-6319.

Zava, D. T., B. Landrum, K. B. Horwitz and W. L. McGuire (1979). Androgen receptor assay with $\left({ }^{3} \mathrm{H}\right)$ methyltrienolone ( $\mathrm{R}$ 1881) in the presence of progesterone receptors. Endocrinology 104, 10071012. 